\title{
Cooperation and Interaction between Village and Sub-District Government in Administration Services Innovation: An Evidence in Lampung Province Indonesia
}

\author{
Henni Kusumastuti ${ }^{*}$, Bambang Supriyono ${ }^{2}$, Lely Indah Mindarti ${ }^{3}$, Alfi Haris Wanto ${ }^{4}$ \\ ${ }^{1}$ Faculty of Administrative Science, University of Sang Bumi Ruwa Jurai Lampung \\ ${ }^{2-4}$ Faculty of Administrative Science, University of Brawijaya Indonesia \\ *Correspondent email: hennirek19@gmail.com
}

\begin{abstract}
This study briefly analyzes the interaction process between village and sub-district government actors in the management of population administration service innovation. The research method used is a qualitative descriptive approach. The data were obtained through primary data and secondary data. Qualitative data analysis begins with collecting data through interviews and studying relevant various documents which related to the object of research, then reporting the results of the research. The results showed that there was an imbalance in the process and interaction between actors, the village government and the Village Consultative Body. The head of a village at the end of his term is not required to provide a report so that the evaluation function of the performance assessment does not run optimally. However, the governance of public service innovation in several villages in South Lampung has involved universities through various collaborations such as the implementation of community Service and research activities. The findings also reveal that research and partnership activities optimize improving the service administration system. Furthermore, the actors have played a role in carrying out the socialization of the implementation of innovation programs to accelerate the realization of independent villages
\end{abstract}

Keywords:

Cooperation Government, Interaction Government, Administration Services

Article Received: 18 October 2020, Revised: 3 November 2020, Accepted: 24 December 2020

\section{INTRODUCTION}

The dimension of public services which is regulated based on Law No.6 of 2014 concerning villages emphasizes that village regulation aims to improve public services for villagers in order to accelerate the realization of public welfare. This can be achieved if the village government actors have the commitment, duties and responsibilities in providing services to the village community. Besides, the cooperation and interaction of actors are very important factors in achieving common goals. A commitment that collaboration is indispensable to meet public interests and community demands (Agranoff \& Mcguire, 2001; Bryson et al., 2015) and more studies show the role of government and government institutions at various levels to collaborate (Trygg, 2018).
One type of public service that requires cooperation and interaction between government actors due to its sustainable nature and must be owned by the village community is population administration services. In Indonesia, documentary evidence includes ownership in the form of Identity Cards and Family Cards, Disability Certificate, Cover Letter for Birth Certificate, Cover Letter for Death Certificate, Cover Letter for Divorce Certificate, Cover Letter for Marriage Deed, Marriage Cover Letter and Cover Letter for Coming / Moving Domicile. Conceptually, cooperation is often defined as a number of individuals or organizations identified as being involved in a working relationship with each other in achieving common goals (Huxham et al., 2007). Thus it can be said that cooperation and interaction between government 
actors consisting of sub-districts, village heads, heads of Village Consultative Body or known as BPD, heads of Village community institutions or known as LKD and village staff have an important and decisive role in realizing the success of services and ensuring that village communities have population administration documents.

In particular, the BPD is regulated through the Minister of Home Affairs Regulation No. 110/2016 on Village Consultative Bodies or BPD where is accommodate and channel the aspirations of the village community. Supervising the performance of the Village Head, respecting the socio-cultural values and customs of the village community. While, according to Minister of Home Affairs Regulation No. 18 of 2018 concerning Village Community Institutions are a forum for community participation, as partners to the village government, participate in planning, implementation and supervision of development, as well as improving village community services.

The focus and responsibility carried out by village government actors is manifested in their roles and responsibilities as regulators, facilitators and catalysts for village communities to encourage and realize participatory and innovative public services. Emphasized by Zaman (2012) and (Tellander \& Horst, 2017) that policy actors are a determining factor for the success of development programs and the ability of actors to make policy innovation is needed to be able to solve service problems (Sururi, 2016). In addition, more studies show that the role of government and government institution is directed towards new ways of collaborating (Trygg, 2018). In this case, village government actors should be able to play the role and position as the main actor in village-level public service policies by involving village communities in creating creative and innovative policies. Cooperation between private and public organizations is seen as a way to solve public problems (Bryson et al., 2006; Kettl, 2015). There is an increasing consensus that collaboration is necessary to meet many of the most difficult public challenges in society (Agranoff \& McGuire, 2001;
Bryson et al., 2015). This ague line with the change in the paradigm of public services that can create conditions for each member of society to develop their abilities, initiatives and creativity.

This study was conducted in Indonesia, which has several problems related to the government of population administration services. Initial observations show that the existing conditions of population administration services in several villages in the sub-districts in Lampung Province still have various obstacles, such as inadequate implementation of the distribution of authority between village officials, low competence of the Village Consultative Body or BPD both in terms of formal education levels and special abilities related to the demands of their duties and responsibilities, village government services are manual, and conversely not all villages in the subdistrict have a village representative office in the administration of population administration. Therefore, these problems ultimately have an impact on in optimal services. The community, especially in terms of service time provided.

Previous study conducted with Wanna (2006) documented that dimension of cooperation between local governments in Indonesia is divided into 2 dimensions, first, coverage at the scale and level of cooperation and based on the context, objectives or motivation of the collaborative activity. This dimension focuses on the level of activity carried out at the collaborative level and to what extent the collaboration is involved. Second, collaboration is not done in a vacuum context. In this case, it is necessary to have clarity of the context, choices, goals, and motivations of the actors who wish to collaborate. Ansell \& Gash (2018) also confirms that collaborative government is increasingly being seen as a proactive policy instrument, where collaborative strategies can be used on a larger scale and extended from one local context to another. Then a collaboration requires the attention of various social elements including deliberation, trust, and leadership (Kossmann et al., 2016). 
Based on the discussion above, this study analyzing how the processes and interactions between village and sub-district government actors in the governance of population administration service innovations. The process and interaction between village and sub-district government actors in the management of population administration service innovation in several villages in the sub-district in the Lampung Province aims to identify initial and basic information about who is affected by the government of public service innovation. For the context of the research being carried out, stakeholder analysis is needed to explain the processes and interactions between village and subdistrict government actors in population administration services so that it can be said that through stakeholder analysis, initial and basic information can be identified about who is affected by administrative service government demography (positive or negative impact); who can influence the population administration service government policies / programs (positive or negative) and which individuals or groups need to be involved in population administration service governance.

\section{LITERATURE REVIEW}

The implementation of the regional autonomy policy states that the authority of a Village covers the areas of village governance, village development, village community development, and village community empowerment based on community initiatives, origin rights, and village customs (Kusumastuti et al, 2020). This authority has an impact by giving birth to the recognition of the village as a subject of active development in the provision of broader and more independent public services, by exercising it based on the principles of sovereign, democratic, participatory and prosperous village government services (Kang'ethe, 2015). In this case, the village government endeavors to accommodate the demands of the village community's needs and make a transformation in service delivery. This is in accordance with the essence of decentralization and regional autonomy policies, namely bringing public services closer to rural communities in accordance with the principle of regional autonomy as the authority to regulate regional government affairs according to their own initiative and based on the aspirations of the local community (Muluk, 2008).

Evidences from previous studies stated that the implementation level, collaboration between actors can be analyzed through five types of interactions, namely decisional, Anticipated Reaction, Decision Making, Systemic and Dynamic Decision (Sururi, 2020). Furthermore, stakeholder analysis as parties who influence or are influenced by decisions or actions (Reed et al. 2009). Stakeholder analysis becomes an important matter, due to analysis of stakeholder is a methodology for understanding a system and for assessing the impact of system changing on the system, as well as the key to identify and assess the stakeholders' interest (ODA, 1995; Grimble, 1998). According to Bryson (2004) the analysis of stakeholders also have purposes, there are 1) avoiding policies that "fail" because policymakers considered a failure to know the interests and information of key stakeholders; 2) it would be connected to the many parties involved globally; 3) as one an important aspect in problemsolving; 4) improving the organizational performance; 5) assist in successfully achieving goals of public organizations and 6) make important contributions to creating value through their impact on functions or activities in the management strategy.Therefore, stakeholder analysis is needed to explain the processes and interactions between village and sub-district government actors in population administration service governance.

\section{RESEARCH METHODS}

This research uses descriptive qualitative approach. A qualitative approach is used to describe the reality on the ground and obtain the accuracy of facts in the field with the correct interpretation. The research was conducted for 9 months of observation, which was carried out from January 
2019 to September 2019. The location of this research was conducted in several villages in Jati Agung sub-district, South Lampung Regency.

This study uses primary and secondary data. Primary data is obtained through participants who have been selected according to predetermined criteria. For further conduct interviews through direct interaction. The key informants as main participants selected based on purposive sampling technique, which fulfils the criteria are required. Based on several criteria and the determination of respondents as informant participant have selected on certain considerations. The criteria for determining the main informant are the competence and mastery of the information and data required. Meanwhile, the secondary data in this study were obtained through searching data relevant to this study from various kinds of literature such as journals, books, print and electronic media. The data is analysed and described in the form of narrative data. Furthermore, qualitative data analysis begins with data collection by interviewing participants by studying various documents related to the object of research. In The next stage, the researcher interpreted and reported the results of the study simultaneously. All information obtained from informants is processed, both orally and in writing. At the end of the stage is a comprehensive data analysis.

FINDING AND DISCUSSION

\section{Result Study}

This study analyzes the processes and interactions between village and sub-district government actors in the governance of population administration service innovations. Participants in this study were obtained from several villages in Jati Agung Subdistrict, South Lampung Regency. The aim of analysis to identify preliminary and basic information about who is affected by the governance of public service innovations (positive or negative impacts). The result study found that interaction between these actors is based on the structure and function in the implementation of democracy in the village which is regulated by the Village Law where the Sub-district is the apparatus of the sub-district which functions, namely: 1) providing guidance to the village, 2) village administration as the organizer of the village government, 3) Village Consultative Body or BPD as an institution that has government functions, namely legislation, representation of aspirations, 4) supervision and Village Community Institutions or LKD as a forum for empowering village communities who also participate in planning and implementing development; and 5) Village Deliberations as the highest forum for strategic decision making in the village. The following is a picture of the process and interaction between village and sub-district government actors in population administration service governance as follows:

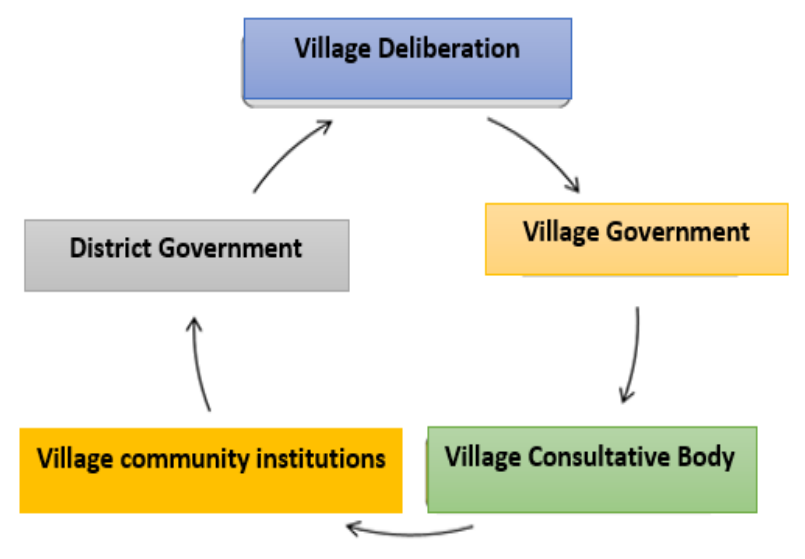

Figure 1 Process and Interaction of Actors in Administration Service Government 
The description of the research results shows that the processes and interactions between village and sub-district government actors in the management of population administration service innovation have been going well, this can be seen from the interaction between villages and sub-districts, such as the provision of facilities from the sub-district to the village to conduct various trainings, education, guidance and guidance and vice versa The village invites the sub-district to attend the village-level Development Planning Deliberation to provide advice and input to the village and ensure that village development activities are running well and in accordance with planning

This finding shows that the sub-district organization as a regional apparatus at the subdistrict level has played a role and functions to provide guidance and supervision of village government activities, the implementation of activities such as the BUMDES workshop held in Jati Agung sub-district is one form of interaction carried out by the sub-district through guidance and improvement guidance. the capacity of village officials in the management of village financial service innovations. Support from the sub-district in every public service activity at the level is expected to have a positive impact on the sustainability of village-level public services according to community expectations. Interactions that are built based on the principles of accountability, transparency and participation will create synergies between optimal service policy actors. Facilitation of coaching activities by the sub-district towards the village government apparatus in accordance with Law Number 23 of 2014 concerning regional governance where the role and function of the head of Sub-district is as a supervisor and supervisor of government activities in villages and sub-districts, although on the other hand, the sub-district as the technical coach of the village still has to increase its capacity and performance

\section{Discussion}

The application of actor interaction supported by checks and balances is an important factor in the success of public service innovation governance. In this case, the government function is carried out by the village government and the supervisory function, representation of aspirations and legislation is carried out by the Village Consultative Body or known as BPD. However, the existing conditions based on the results of research in several villages in South Lampung Regency indicate that there is an imbalance of interaction between actors, namely the village government and the Village Consultative Body. While the end of his term of office work, the Village Head is not required to provide an end-of-term report to the BPD. In field happened that is the BPD evaluation function which assessing the achievements of Village Medium Term Development Plan or often abbreviated as the RPJMDes is does not work. Thus, it shows that there is no clear process and interaction of policy actors so that the procession identifies initial and basic information about who is affected by the governance of public service innovation (positive or negative impacts); who can influence public service innovation governance policies / programs (positive or negative); which individuals or groups need to be involved in governance of public service innovation is not implemented properly. According to Myhren et al. (2018) based on these conditions, it is necessary to analyze open service innovations that will be used for incremental and radical service innovations. This is intended so that the public sector can innovate open services as an option both through incremental and radical patterns in the implementation of village governance.

The results of the study also show that the governance of public service innovation in several villages in South Lampung involves universities through various collaborations such as the implementation of Community Service and research activities. This collaboration in research and community service has a positive impact on 
government management in villages and subdistricts, including the results of the collaboration carried out in Desa Summon, namely training in village financial systems by involving private universities in Lampung. The partnership activity aims to optimize the village service administration system in Fajar Baru Village, Jati Agung Subdistrict. In addition, the activities carried out by the community service team from state universities in Lampung were training in government administration governance for apparatus. In this village development activity, the development of natural resources in Margorejo Village is carried out to become an argo tourism village and the development of Small and Medium Business Units or known as MSMEs in the development of catfish farming. All these collaborative and innovative activities can be confirmed as the Triple Helix concept (Dzisah \& Etzkowitz, 2008; Etzkowitz, 2008). The Triple Helix concept is the development of public service innovation governance requiring the support of cooperation between intellectuals, business and government. A premise with the Triple Helix circulation is a field that can mobilize people to increase creativity, ideas and skills.

Theoretically, according to Behn (1998), there are four different processes in implementing an innovation that is commonly developed, among others: (1) Diffusion, which is an innovation process that is unintentional, takes place spontaneously (spontaneously), a process that is not hidden-hand is done by someone when they hear about an innovation and conclude that it is useful to try. This is often referred to as "the somehow people will learn how to get a better approach". (2) Transfer, namely the exchange of ideas informally and practiced by a network between individuals, usually a network of friends and colleagues in a profession (work) in the same policy area, although different organizations or work areas. Usually called "the friends will tell friends about how they are getting a better approach". (3) Propagation, which is an effort in the form of thought or planning that has been prepared in advance (perhaps by innovators, individuals outside organizations, or higher levels of government) to create a dialogue strategy for education and assistance to transfer innovation from other people (parties). This is often referred to as "the we ought to help people learn how to get a better approach". (4) Replication, namely a conscious effort made by organizations (individuals in the organization) who work hard to improve, by actively seeking ideas, policies, programs and practices that have been successful and can be adopted. This type of replication strategy is often referred to as "the we want to learn from others who know how to get a better approach".

Interaction between actors in the administration of village governance based on the structure and function of democracy in the village which is regulated by the Village Law, namely the Subdistrict as the apparatus of the sub-district area which functions to provide guidance to the village; village administration as the organizer of village administration; The Village Consultative Body (BPD) as an institution that has government functions, namely legislation, representation of aspirations, and supervision and the Village Community Institution (LKD) as a forum for empowering village communities who also participates in planning and implementing development; and Village Deliberations as the highest forum for strategic decision-making in the village.

Furthermore, based on research facts, through the Village Community Empowerment Service in South Lampung Regency held a socialization of the implementation of an innovation program to accelerate the realization of an independent village and Jati Agung sub-district is one of the subdistricts included in the cluster one innovation exchange activity. That stakeholders are all those who influence or are influenced by decisions or actions (Reed et al., 2009). Stakeholder analysis is important, because stakeholder analysis is a methodology for gaining an understanding of a system and for assessing the impact of changes on the system, as well as a way to identify and assess 
the interests of these key stakeholders (ODA, 1995) and (Grimble, 1998).

The Village Innovation Implementation Team is a community group implementing the Village Innovation Program which is located at the subdistrict level and is tasked with managing the Operational Fund for Village Innovation and Knowledge Management Activities. The Village Innovation Activity Operation Fund is used to finance operations and support activities for Villages that are committed to replicating innovation through the APBDes and to finance knowledge management, documentation and dissemination of innovation activities. This team was formed through a deliberative forum in the sub-district that involved representatives from each village. According to Bryson (2004) and Garaika \& Jatiningrum (2020) explined stakeholder analysis has several functions, there are avoid failure of policies the interests and information of key stakeholders, would be connecting to many parties, critical aspect in problem solving, improving the performance of organizational, the reach in organizational goals and 6) as contribution to activity in the management strategy. In the perspective of regional district growth, it can also be stated that growth in district government that is on eventually improve human development, and become an indicator creation of capable development encourage government and economic growth. Therefore, with good management and ability in absorbing and managing the sources of growth regional economy, both to do with technology as well as institutional public administrative service as an important means of achieving optimal village and district growth.

\section{CONCLUSION}

The result study found that in several villages which located in South Lampung Regency Lampung Province imbalance in the process and interaction between village government and the Village Consultative Body or known as BPD. The study also found that at the end of his term of office,
Head of village is not required to provide an endof-term report to the BPD so that the BPD evaluation function in assessing the achievements of the RPJMDes does not work.

The public service innovation governance in several villages in South Lampung has involved several universities both public and private have positive effect for the communities. Activities through various collaborations such as the implementation of Community Service and research activities improving the public services activities in the village and sub-district. The results of cooperation in partnership and community service activities have a positive impact in optimizing the village and sub-district service administration system in the South Lampung Regency. Furthermore, actors have also played a role in disseminating the implementation of innovation programs to accelerate the realization of independent villages. The limitation of this study is that this study was conducted only in South Lampung sub-district in Lampung Province. Future research can expand the scope of the research area so that the result could be optimal analyzed and generalized. Future research can analyze public service innovation governance by referring to the Triple Helix system. Optimizing the role of intellectuals and industry in government governance cooperation.

\section{REFERENCES}

[1] Agranoff, R., \& McGuire, M. (2001). Big Questions in Public Network Management Research. Journal of Public Administration Research and Theory, 11(3), 295-326. https://doi.org/10.1093/oxfordjournals.jpar t.a003504

[2] Bryson et al. (2015). Bryson, J. M., Crosby, B. C., \& Stone, M. (2015). Designing and Implementing Cross-Sector Collaborations: Needed. Public Administration Review, 75, 647-663.

\section{https://doi.org/10.1111/puar.12432}

[3] Trygg, K. (2018). Understanding collaboration and local development-a 
Swedish case study on different actors' roles and perspectives. Scottish Geographical Journal, 134(3-4), 172-183. https://doi.org/10.1080/14702541.2018.14 $\underline{71156}$

[4] Huxham, C., Vangen, S., \& Eden, C. (2007). The Challenge of Collaborative Governance. Public Management: An International Journal of Research and Theory, 2(3), 337-358. https://doi.org/10.1080/147190300000000 $\underline{21}$

[5] Zaman, A. (2012). Understanding Policy. SSRN, 29-67. https://doi.org/10.2139/ssrn.2080217

[6] Tellander, E., \& Horst, C. (2017). A Foreign Policy Actor of Importance? The Role of the Somali Diaspora in Shaping Norwegian Policy towards Somalia. Foreign Policy Analysis, 15(1), 136-154. https://doi.org/10.1093/fpa/orx012

[7] Sururi, A. (2016). Inovasi Kebijakan Publik (Tinjauan Konseptual dan Empiris). Sawala, 4(3), 1-14.

[8] Bryson, J. M., Crosby, B. C., \& Stone, M. M. (2006). The design and implementation of cross-sector collaborations: Propositions from the literature. Public Administration Review, 66 (SUPPL. 1), 44-55. https://doi.org/10.1111/j.15406210.2006.00665.x

[9] Kettl, D. F. (2015). The job of government: Interweaving public functions and private hands. Public Administration Review, $75(2)$, 219-229.

https://doi.org/10.1111/puar.12336

[10] Bryson, J. M., Crosby, B. C., \& Stone, M. (2015). Designing and Implementing Cross-Sector Collaborations: Needed. Public Administration Review, 75, 647663. https://doi.org/10.1111/puar.12432.

[11] Wanna, J. (2006). Collaborative government: meanings, dimensions, drivers and outcomes. Collaborative Governance, 3-12.

[12] Ansell \& Gash (2018) Ansell, C., \& Gash,
A. (2018). Collaborative Platforms as a Governance Strategy. Journal of Public Research And Theroy, 16-32. https://doi.org/10.1093/jopart/mux030

[13] Kossmann, C. M., Behagel, J. H., \& Bailey, M. (2016). Action and inertia in collaborative governance. Marine Policy, 72 ,

21-30.

https://doi.org/10.1016/j.marpol.2016.06.0 $\underline{07}$

[14] Kusumastuti, H., Supriyono, B., Mindarti, L I., Wanto, A. H. (2020). The capacity and innovation of services in organizing village governance in Indonesia. Opción 36 (26), 1681-1696

[15] Kang'ethe (2015). Exploring the effects of cultural attrition as a recipe of lost human dignity and dented identity the case of selected African cultures. Journal of Sociology and Social Anthropology. 6(3), 429-434.

[16] Muluk, M. (2008). Knowledge Management, Kunci Sukses Inovasi Pemerintah Daerah. Cetakan Pe. Malang Indonesia: Bayumedia Publishing. Indonesia.

[17] Sururi, A. (2020). Collaborative Governance Actor in the Revitalization Program of Old Banten Religious Tourism Area. Policy \& Governance Review, 4(2), 128. https://doi.org/10.30589/pgr.v4i2.216

[18] Reed, M. S., Graves, A., Dandy, N., Posthumus, H., Hubacek, K., Morris, J., Prell, C., Quinn, C. H., \& Stringer, L. C. (2009). Who's in and why? A typology of stakeholder analysis methods for natural resource management. Journal of Environmental Management, 90(5), 19331949.

https://doi.org/10.1016/j.jenvman.2009.01. $\underline{001}$

[19] ODA. (1995). Guidance note on stakeholder analysis for aid projects and programmes. 1-10.

https://doi.org/10.1016/B978-0-12-

415829-0.15006-3 
[20] Grimble, R. (1998). Stakeholder methodologies in natural resource. SocioEconomic Methodologies Best Practice Guidelines, 12. https://doi.org/https://doiorg.ezproxy.otago.ac.nz/10.1007/s10862$\underline{\text { 018-9649-7 }}$

[21] Bryson, J. M. (2004). Public Management Review. Public Management Review, 6(1), 21-53.

[22] Myhren, P., Witell, L., Gustafsson, A., \& Gebauer, H. (2018). Incremental and radical open service innovation. Services Marketing, 32(2), 102-112. https://doi.org/10.1108/JSM-04-2016-0161

[23] Dzisah, J., \& Etzkowitz, H. (2008). Triple helix circulation: the heart of innovation and development. International Journal of Technology Management and Sustainable Development, $\quad 7(2), \quad 101-115$. https://doi.org/10.1386/ijtm.7.2.101_1

[24] Behn, R. D. (1998). The new public management paradigm and the search for democratic accountability. International Public Management Journal, 1(2), 131$164 . \quad$ https://doi.org/10.1016/S10967494(99)80088-9

[25] Garaika, H. M, \& Jatiningrum, C. (2020). The Impact Of Human Resources, Social Capital And Economic Infrastructure On Economic Growth: Evidence In Indonesia. Palarch's Journal of Archaeology of Egypt/Egyptology, 17(6), 11395-11408.

[26] Irviani, R., Jatiningrum, C., \& Kasmi. (2017) Pengaruh Pendapatan Daerah dan Kinerja Keuangan terhadap Pertumbuhan Ekonomi dan Kesejahteraan Masyarakat pada Kabupaten/kota Provinsi Lampung. Akuntabilitas, 11(1), 1-14 